\begin{tabular}{|l|l|l||}
\hline \multicolumn{2}{|c|}{ PublisherInfo } \\
\hline \hline PublisherName & $:$ & BioMed Central \\
\hline \hline PublisherLocation & $:$ & London \\
\hline \hline PublisherImprintName & $:$ & BioMed Central \\
\hline \hline
\end{tabular}

\title{
Gene therapy monkey business
}

\begin{tabular}{|l|l|l||}
\hline \multicolumn{2}{|c|}{ ArticleInfo } \\
\hline \hline ArticleID & $:$ & 4561 \\
\hline \hline ArticleDOI & $:$ & $10.1186 /$ gb-spotlight-20020823-01 \\
\hline \hline ArticleCitationID & $:$ & spotlight-20020823-01 \\
\hline \hline ArticleSequenceNumber & $:$ & 227 \\
\hline \hline ArticleCategory & $:$ & Research news \\
\hline ArticleFirstPage & $:$ & 1 \\
\hline \hline ArticleLastPage & $:$ & 2 \\
\hline \hline & & RegistrationDate : 2002-8-23 \\
\hline ArticleHistory & $:$ & OnlineDate \\
\hline \hline ArticleCopyright & $:$ & BioMed Central Ltd2002-8-23 \\
\hline \hline ArticleGrants & $:$ & \\
\hline \hline ArticleContext & $:$ & 130593311 \\
\hline \hline
\end{tabular}




\section{Jonathan B Weitzman}

Email: jonathanweitzman@hotmail.com

Adeno-associated viruses (AAVs) belong to the Paraviridae family and are being developed as potential vectors for human gene therapy. In the Early Edition of the Proceedings of the National Academy of Sciences, Gao et al. report the isolation of novel non-human primate AAVs. They aligned known primate and non-primate AAV genome sequences and selected conserved regions for amplification by PCR. This allowed them to isolate two new viruses, AAV7 and AAV8, from the DNA of rhesus monkey heart tissues. Gao et al., then produced AAV vectors packaged with AAV7 and AAV8 capsid proteins and tested the chimeric virions; the non-human AAV reacted poorly with antibodies against human AAV serotypes. Furthermore, when they looked at in vivo performance they found that the new viruses were very efficient gene-delivery vectors for mouse skeletal muscle and liver. The low immunogenicity and favourable tropism of these vectors suggest that they may be useful tools for human gene therapy applications.

\section{References}

1. Adeno-associated virus vectors for gene therapy: more pros than cons?

2. Proceedings of the National Academy of Sciences, [http://www.pnas.org]

3. Novel adeno-associated viruses from rhesus monkeys as vectors for human gene therapy, [http://www.pnas.org/cgi/doi/10.1073/pnas.182412299] 